\title{
Effects of Smoke Water on Seeds Germination, Seedling Growth of some Vegetables and Green Yield Productivity of Phaseolus vulgaris
}

\author{
H. H. Abou El-Nour.
}

Vegetable Research Department, Horticulture Research Institute, Agriculture Research Center, Giza, Egypt

*Corresponding author E-mail: wittylight@Gmail.com (H. Abou El-Nour)

\begin{abstract}
Four concentrations $(0.5 \%, 1 \%, 1.5 \%$ and $2 \%)$ of smoke water extract beside tap water as control were used as soil drenching during seed germination and seedlings growth of pepper, tomato, carrot, onion, celery and lettuce cultivated in greenhouse, or in combination with foliar spray to study its effects on the productivity of Phaseolus vulgaris in an open field. The results indicated that all smoke water concentrations encouraged seed germination percentage and rate of pepper, celery and lettuce. However, both tomato and onion seeds positively responded to smoke water at the concentration of $1.0 \%$ compared to highly concentrated $(1.5 \%$ and $2 \%)$, which causes an inhibitory effect. Meanwhile, the low level of smoke water $(0.5 \%)$ was sufficient to obtain superior values on carrot seeds germination tests compared to the other levels. Also, the results indicated that the high concentration of smoke water extract $(2 \%)$ was enough to support pepper, carrot and lettuce seedlings growth parameters expressed as height, fresh and dry weight, number of leaves and chlorophyll content. On the other side, all smoke water levels had negative effects on tomato, onion and celery seedlings growth. The maximum results of snap bean vegetative growth, green pod yield and the accumulation of plant dry matter percentage were obtained using smoke water at the $1.5 \%$ level as foliar spray combined with soil drenching. Meanwhile, the high level of smoke water (2\%) led to a decrease in snap bean vegetative growth, total green pod (ton/fed), pod characters and pod chemical contents in the two seasons.
\end{abstract}

Key Words: Smoke water, seedlings and Phaseolus vulgaris.

\section{INTRODUCTION}

The germination process is considered an important phase in the plant life cycle which permits the plant to continue growing and produce a new generation. Generally, there are varied causes that delay germination of some vegetable seeds despite the presence of germination favorable conditions like water, oxygen and temperature such as the hard coats as in case of carrot and celery which lead to failure of seeds in imbibe the water thereby prevents the occurrence of chemical and physical transformation processes in seeds (Seymour, 2007). Pepper is a warm-climate crop, and its seeds are sensitive to storage conditions and lose germination potential within a short time, particularly under adverse storage conditions (Priestly, 1986) as well as onion seeds which decreased its viability and vigor through time due to increased lipid peroxidation, decreased activities of several free radical and peroxide scavenging enzymes (Rao et al., 2006).

Smoke water, derived from burned plants, is a technique that relies upon the burning of agricultural cellulosic residual under controlled air pressure then collects the rising smoke as bubbles in distilled water (De-Lang and Boucher, 1990). Generally, all plant materials are suitable for the preparation of smoke water (Jager et al., 1996). The aqueous smoke water can be diluted in ratios of 1:250; 1:500; 1:1000; $1: 1500$ and 1:2000 (v/v) and stored for long periods at room temperature without any loss to its biological activity (Brown and van Staden, 1997). The highly active germination promoting compound in smoke water derived from burned plants (van Staden et al., 2004) and cellulose (Flematti et al., 2004) had been identified as butenolide, 3methyl-2H-furo [2,3-c]pyran-2-one, which is effective at very low concentration $1 \mathrm{ppb}$ (Govindaraj et al., 2016). Recently, this compound has been named Karrikinolide (KAR1-6) as reported by Commander et al. (2008) and Flematti et al. (2009). The beneficial order of smoke water on seed germination, seedling growth and plant development can be remarked even under adverse conditions, such as heat stress, and low osmotic potentials as well as in arid and semi-arid regions (Kulkarni et al., 2011). Smoke water induces a remarkable increase in seed germination in over 1200 species from 80 genera (Dixon et al., 2009). For example, it encourages germination seeds of celery (Thomas and van Staden, 1995) and Zea mays (Waheed et al., 2016; Aslam et al., 2017). On lettuce, it was reported that seeds treated with smoke water extract resulted in the highest germination tests, i.e., germination 
percentage, peak value, index and fresh weight (Kamran et al., 2017). The effect of smoke water on seedlings and plant growth was investigated. The results indicated that smoke water treatment has the potential to become a valuable tool in horticulture, i.e., smoke water stimulated tomato seedling roots growth (Taylor and van Staden, 1998). The prevalence seedlings growth and shoot length of tomato, okra and bean were obtained with seeds treated by smoke water (van Staden et al., 2006). Moreover, smoke water dilution (1:500, $\mathrm{v} / \mathrm{v}$ ) improved the seedlings weight of tomato and okra as recorded by Kulkarni et al. (2007). On papaya seedlings growth, Chumpookam et al. (2012) illustrated that all smoke water concentrations ( $1 \%$ to $10 \%, \mathrm{v} / \mathrm{v})$ promoted multiple growth attributes of seedlings. The positive impact of smoke water on the plant growth parameters and yield components was recorded by Kulkarni et al. (2008) on tomato and Kulkarni et al. (2010) on onion.

The aim of this study is to evaluate the effects of using smoke water at different concentrations on seeds germination and seedlings growth of some local vegetables in addition to plant growth, green yield quality and productivity of Phaseolus vulgaris L.

\section{MATERIAL AND METHODS}

This study was carried out in the ElKassasein station Farm, Ismailia Governorate, Horticulture Research Institute, during the two seasons of 2019 and 2020.

\section{Preparation of smoke water extract:}

The smoke water extract was prepared using dried tree leaves of Casuarina spp. which were collected from El Kassasein station, Agriculture Research Center, Ismailia Governorate during the summer seasons of 2019 and 2020. Three Kg of dried Casuarinas leaves were burned into a metal drum at the size of 200L. Hence, the obtained smoke from pruned leaves was pushed by hand compressed air and bubbling through a glass jar containing $500 \mathrm{ml}$ of distilled water for 45 min as described by (van Staden et al., 2004). After that, the extract was purified by filtering through Whatman No. 1 filter paper and divided into four concentrations $(0.5 \%, 1 \%$, $1.5 \%$ and $2 \%$ ). The previous concentrations besides tap water ( 0 concentration) as a control treatment were used in two separate experiments. In the first experiment, the previous concentrations were used as water irrigation of trays cultivated with seeds of six local vegetable plants (lettuce, carrot, pepper, tomato, onion and celery). In the second experiment, the previous concentrations were used and added as soil drenching beside foliar spray for Phaseolus vulgaris L., cv. Paulista, cultivated in the open field.

The chemical composition of the smoke extract was summarized in Table (1).

\section{First experiment:}

Effect of smoke water extract on germination process and seedlings vegetative growth of some vegetable plants:

This experiment was conducted in the greenhouse of El-Kassasein Station Farm, Agriculture Research Center, Ismailia Governorate during the summer seasons of 2019 and 2020. Seeds of six local varieties of vegetable plants, i.e., lettuce (Lactuca sativa L.), carrot (Daucus carota L.), pepper (Capsicum annum L.), Tomato (Solanum lycopersicum L.), onion (Allium cepa L.) and celery (Apium graveolens L.) which were sown in seedling trays filled with peat moss: vermiculite 1:1 $(\mathrm{v} / \mathrm{v})$ on September $11^{\text {th }}$ and $15^{\text {th }}$ in 2019 and 2020, respectively. Other agricultural processes were done in trays through the nursery stage according to the recommendation of the Ministry of agriculture except for the irrigation process which was treated using different levels of smoke extract $(0.0,0.5 \%, 1 \%, 1.5 \%$ and $2 \%$ ) as needed till 30 days. The experiment was arranged in a randomized complete block design with three replicates. The germination process was checked to record germination testes and continues every day until day-15. The criterion used for germination was taken as the emergence of $3 \mathrm{~mm}$ radical at the time of observation according to Odoemena (1988).

\section{Data recorded:}

\section{Germination process:}

Germination percentage $($ GP $\%)=($ Number of emerged seedlings / Total number of seeds) $\times 100$, according to (Adetimirin, 2008).

Germination rate $(\mathrm{GR})=\mathrm{N} 1 \times \mathrm{D} 1+\mathrm{N} 2 \times \mathrm{D} 2$ + N3 x D3 + -------- / Total germinated seeds. Where: $\mathrm{N}=$ Number of germinated seeds per day, $\mathrm{D}=$ Number of days from the start of the count, according to (Scott et al., 1984).

\section{Seedlings vegetative growth:}

\section{Data recorded:}

Seedlings length $(\mathrm{cm})$, fresh weight $(\mathrm{g})$, number of leaves/seedlings, seedlings dry weight (g) and total leaf chlorophyll content were measured. Ten seedlings were taken from each treatment and dried at $70 \mathrm{C}^{\mathrm{o}}$ till 
constant weight, and the average dry weight of whole seedlings was determined using the standard methods as illustrated by (A.O.A.C., 1990). Total leaf chlorophyll content was measured using Minolta chlorophyll meter SPAD-501. The experiment was arranged in a complete randomized design in three replicates.

\section{Second experiment.}

The present investigation was conducted in the open field of El-Kassasein station Farm, Ismailia governorate, Horticulture Research Institute, during the two early summer seasons of 2019 and 2020. Seeds of Phaseolus vulgaris L., cv. Paulista (Makkah, Co., Cairo) were sown, at $5 \mathrm{~cm}$ apart between plants on one side of the ridge. The experimental unit area was $10.5 \mathrm{~m}^{2}$ which contained 5 ridges with $3.5 \mathrm{~m}$ length and $60 \mathrm{~cm}$ width for each. The experiments were arranged in a randomized complete block design with three replicates including nine treatments from the previous concentrations of smoke extract $(0.5 \%, 1 \%$, $1.5 \%$ and $2 \%$ ) included four treatments as foliar spraying and four treatments as soil drenching jointly with foliar applications beside the control treatment ( 0 concentration, tap water). Other agricultural practices were done according to the recommendation of the Ministry of Agricultural. Random soil samples were taken before planting for chemical and mechanical analysis as described by Chapman and Pratt (1961) and Jackson (1965). The farm had a sandy loam soil texture; physical and chemical analyses were shown in Table (2).

\section{Data Recorded:}

\section{Vegetative growth characteristics:}

Five plants were chosen randomly from each plot at flowering stages to determine: Plant length $(\mathrm{cm})$ and fresh weight ( $\mathrm{g} /$ plant), number of leaves and branches per plant. Total leaf chlorophyll content was measured using Minolta chlorophyll meter SPAD-501. The dry matter accumulation was determined by takeing a random sample of three plants from each plot and dried at $70 \mathrm{C}^{\mathrm{o}}$ till constant weight

Dry matter accumulation $(\%)=($ Dry weight / Fresh weight) x 100.

\section{Yield and pod characters:}

A sample of ten fresh green pods at the marketable stage of Paulista cv., were randomly taken from each plot at the second picking to determine the following data: pod length $(\mathrm{cm})$, pod diameter $(\mathrm{cm})$, average pod weight (g) and total green pods yield (ton/fed) were estimated (the weight of all pickings).

\section{Pod chemical contents:}

A sample of $0.2 \mathrm{~g}$ from fine powder of dry pods was digested in a mixture of sulphuric and perchloric acids according to Piper (1947) to estimate Protein (\%) and Potassium (\%) was determined by flame-photometrically as described by Brown and Lilleland (1946) and phosphorus (\%) was determined according to the methods described by Olsen and Sommers (1982). Carbohydrate was determined in pods calorimetrically according to the method described by Dubois et al. (1956).

\section{Statistical Analysis:}

All data were subjected to statistical analysis according to the procedures reported by Snedecor and Cochran (1982) using Statistix 8 software program and means were compared by L.S.D multiple range tests at the 0.05 level of probability in the two seasons of experimentation.

\section{RESULTS AND DISCUSSION}

\section{First experiment:}

Effect of smoke water extract on germination process and seedlings vegetative growth of some vegetable plants:

\section{Germination process:}

Data presented in Fig. (1 and 2) showed that the germination percentage and rate of tested vegetables seeds (pepper, tomato, carrot, onion celery and lettuce) significantly differed in their response to treatments. The gradual increment on seeds of pepper, celery and lettuce germination percentage and rate, with the transport from the low concentrate $0.5 \%$ to high concentrate $2.0 \%$ of smoke water extract compared to the control treatment (Tap water). The superiority response was marked with celery seeds followed by pepper and lettuce seeds, respectively. While in the case of both tomato and onion, the level $1.0 \%$ of the smoke extract was significantly sufficient to stimulate the germination percentage and rate, however, the higher concentrations 1.5 and $2 \%$ had germination inhibiting effects. Meanwhile, the augmented response of carrot seeds was achieved with the low concentrate (0.5\%) compared to the other smoke water extract levels. The importance of smoke water extract in enhancing the germination processing seeds has been studied by De Lange and Boucher (1990). The potential effects of smoke water in breaking down the germination inhibitors 
were dependent on three major factors. The first one is chemically, hence, Baldwin et al. (1994) proposed that smoke compounds interact chemically with inhibitors in the seed coat, endosperm or embryo, thereby enhancing seed germination. While, Flematti et al. (2009) pointed out that different two or more compounds which have been identified in smoke water acting together and that may be responsible for smoke-stimulated germination such as nitric oxide (NO) and its related nitrogen oxides, carbon dioxide, ethylene and methane (Keeley and Fotheringham, 1998). In another opinion, the enhancing effect of the smoke water may be related to the changes in the synthesis/metabolism of endogenous hormones as a result of smoke seed treatment (van Staden et al., 2000). The second axis in smoke effectiveness in seed germination is a morphological factor where, smoke particles can adhere, persist and be adsorbed to plant surfaces and soil particles thereby plays active role in the germination process by changing the morphology of the seed and causing an intense chemical scarification of the seed surface especially in seeds which have hard coat (carrot in the present study) which prevent water diffusion into the seed (EgertonWarburton, 1998; van Staden et al. 2000). The third axis is a biological effect whereas, various studies attributed the promotion effects of smoke extract to main active compound which has been identified as butenolide which recently named karrikinolid (KAR $)$ (van Staden et al., 2004), this compound is now recognized as a germination cue for many smoke-exposed and smoke non exposed species. The promoting acts of butenolide or $\mathrm{KAR}_{1}$ can be explained by its effect being similar to those of gibberellins and/or cytokinin both of which may promote embryonic development and break seed dormancy in seeds in turn, allows seeds to germinate and emerge faster Merritt et al. (2006), van Staden et al. (2006) and Daws et al. (2007a). Other results suggested that smoke has an influential role in germination seeds, and it could be involved in the early induction of cell cycle activities, thus accelerating radical emergence in germinating seeds and hence promoting a higher germination rate (Jain and van Staden, 2006). The same results were reported on maize by Waheed et al. (2016) who reported that seed germination percentage was improved up to $93 \%$ with smoke compared to control (70\%). In their study about the influence of smoke-derived Karrikinolide $\left(\mathrm{KAR}_{1}\right)$ on pepper seeds germination and rate, Demir et al. (2018) decided that encouragement in both of seeds germination and rate detected to $\left(\mathrm{KAR}_{1}\right)$ at concentration of $10^{-7} \mathrm{M}$ and this effect was more influential on immature seeds than mature seeds. Generally, the promotion effect of smoke water is independent of seed size, shape and plant life form, whether annual, perennial or herbaceous (Drewes et al., 1995). In respect to the negative effect of high levels of smoke water on tomato, onion and carrot seeds germination and rate, these results may be due to the fact that the activity effects of smoke water extract are dependent on seed size, shape, source and $\mathrm{pH}$ of smoke water (Muhammad et al., 2014). Also, presenting of an inhibitory compound belongs to butenolide and identified as 3,4,5-trimethylfuran-2(5H)one or tri-methyl-butenolide (TMB), this compound inhibits seed germination and significantly reduce the effect of the stimulatory compound $\mathrm{KAR}_{1}$ at high concentrations of smoke water treatments as mentioned by Adkins and Peters (2001); Daws et al. (2007b); Light et al. (2009). These results explain the inhibitory effects of SWE at high concentrations on germination tests of tomato, onion and carrot seeds in our study. Similarly, Gupta et al. (2020) concluded that the concentration of TMB in SWE should be much lower that the compounds $\mathrm{KAR}_{1}$ and $\mathrm{KAR}_{2}$ can display their stimulatory effect. At the very low concentrations of these compounds $(0.5 \%)$, the TMB is also simultaneously diluted in turn reducing its inhibitory effect. These results were in harmony with those found by Chumpookam et al. (2012) who reported that the low concentrations of smoke-water $(0.1 \%$ and $0.2 \%, \mathrm{v} / \mathrm{v}$ ) clearly showed significantly potent germination activity in 'Tainung No. 2'papaya seeds and reduced the time to germination.

\section{Seedlings vegetative growth:}

It is clear in Table (5) that the response of tested seedlings to smoke water extract is differing according to the crop and the concentrations. Increasing the concentrations of smoke water from 0.5 to $2.0 \%$ led to significant promoting of the seedling parameters of pepper, carrot and lettuce i.e., fresh/dry weight, plant height and number of leaves in the two growing seasons which recorded the highest results with the level of $2.0 \%$. Meanwhile, all levels of smoke water had significant negative effects on the same previous vegetative parameters in tomato, onion and celery seedlings, whereas the highest results were obtained with the treatment of tap water (control). Our results about the promotive effect of smoke water are 
in agreement with the results of (Chumpookam, et al., 2012) who pointed out that the encouragement act of smoke water might be achieved to promote seedlings uptake of some mineral nutrients or regarding the active component of smoke extract which namely butenolide as mentioned by (van Staden et al., 2004). Also, Merritt et al. (2006); Jamil et al. (2014) and Waheed et al. (2016) deduced that this positive result returned to the gibberellins and/or cytokinin contained in smoke water. On the other side, the increment in seedlings vegetative growth as results to smoke water treatments may be due to its chemical component i.e., catechol and cyanohydrin (Wang et al., 2017), Karrikinolide and cyanohydrin and potassium nitrate ( $\left.\mathrm{KNO}_{3}\right)$ (Serter et al., 2018) beside cellulosederived smoke water and $\mathrm{KAR}_{1}$ as reported by Sunmonu et al. (2016) who deduced that smoke water, KAR 1 and $\mathrm{GA}_{3}$ promote seedlings growth by efficient mobilization of starch reserves from cotyledons/endosperms to other seedling parts by enhancing hydrolytic enzyme activities particularly amylase which reflected on seedlings growth. Moreover, Govindaraj et al. (2016) concluded that smoke water might be potentially used as a seedling growth and vigor stimulus with lesser cost in various plant species.

Concerning the negative influence of smoke water on tomato, onion and celery, it may be returned to fact that the presented of some compounds which had been isolated from smoke water and called tri-methyl-butenolide (TMB) which act as an inhibitory impact on seedlings growth as confirmed by (Papenfus $e t$ al., 2015).

\section{Second experiment:}

\section{Vegetative growth characteristics:}

vegetative growth parameters of bean plants i.e., plant length, number of leaves, number of branches, fresh weight, dry matter accumulation, number of secondary roots and average root length differ according to the levels of smoke water treated either spraying alone or with drenching to the bean plants. Data in Table (6) showed that increasing the smoke water levels from 0.0 to $1.5 \%$ encouraged all previous parameters and reached the maximum values at the concentration of $1.5 \%$, especially when using foliar spray combined with soil drenching (T7). These results are supported by previous work demonstrated by Kulkarni et al. (2011); Aremu et al. (2012) and Abdollahi (2012). They deduced that the beneficial effects of smoke treatments including vigor plant growth and increasing root growth could be returned to the favorable acts of butenolide which isolated from smoke water. Furthermore, the physiological studies mentioned that there are synergistic interactions between the smoke compounds and plant hormones, whereas, Karrikinolide i.e., butenolide, stimulated cell division in the soybean callus bioassay and rooting in the mung bean bioassay (Jain et al., 2008). Based on the foregoing, smoke water has a similar encouraging effect as that obtained from plant hormones which stimulate cell division and increase its number and thus stimulate rooting and increase the absorption surface, thereby the absorption of a nutrient that at the end is reflected in the strong vegetative growth characteristic. These results have been confirmed by Jamil et al. (2014) who pointed out that SW may contain activity like hormones. Also, Singh et al. (2014) reported that smoke-water has been reported to possess gibberellic acid-like activity. On the other hand, the depressed order of smoke water at high level i.e., $2 \%$ on bean vegetative growth (T9) could be returned to present the (TMB) compound that appears to belong to the inhibitory activity acts of the butenolide compound. Adkins and Peters (2001); Daws et al. (2007b); Light et al. (2010).

\section{Yield and pod characters:}

The presented data in Table (7) showed that snap bean yield and pod measurements i.e. pod length, average pod weight as well as total green yield ton/fed were recorded the maximum results corresponding on smoke water concentration $1.5 \%$ (T7). The augmented results of the previous parameters may be due to the strong vegetative plant growth shown in Table (6), reflecting on the yield results. Our previous findings were consistent with that found by Abu Khouder et al. (2019) who reported that the increase in fresh pod yield of snap bean and its components might be attributed to the increase in its vegetative growth and dry matter accumulation. The vigor vegetative growth caused by smoke water treatments induced more photosynthetic and mineral absorption rates, which in turn produced high carbohydrates in plant tissues that gave rise to more cell division and enlargement (El-Zeiny, 2002). This was reflected as producing more pod yield. Nevertheless, the main active compound in SW i.e., butenolide act is similarly like gibberellins and/or cytokinin, as mentioned before, which in turn causes simulation of several metabolic processes that are considered 
very important for the activity of photosynthesis and the accumulation of metabolites in reproductive organs (Jardin, 2015). The vigor root growth is shown in Table (6), and reported by Mohamed et al. (2015) on Vicia faba and Rathod et al. (2015) on French bean and on yield as well as the pod physical quality. Kulkarni et al. (2008\&2010) revealed that smoke water and butenolide increased tomato fruits earlier, number and total yield as well as for onion a significantly higher bulb diameter and bulb weight were obtained in comparing with the untreated plants.

\section{Pod chemical contents:}

With regard to the influence of different concentrations of smoke water extract on pod chemical contents, data in Table (8) showed that the superiority values were obtained with $1.5 \%$ concentration related to all chemical measurements at the two growing seasons, therefore spray snap bean plant with this level was sufficient to raise the accumulate pod chemical contents, i.e., K, P, protein and carbohydrate. On the other hand, the highest concentration of $2 \%$ of smoke water causes a decrease in the above measurements. It could be said that the accumulation of mineral and chemical contents in a pod may be returned to the increase in average root length and number of secondary roots as mentioned in Table (6), which is due to encouragement in nutrient absorptions and accumulation of minerals in plant organs.

\section{CONCLUSION}

From the previous results, it can be concluded that vegetable seeds, i.e., pepper, tomato, carrot, onion, lettuce and celery, showed different responses of germination tests (percentage and rate) according to smoke water concentrations, where seeds of pepper, celery and lettuce appeared positively results with all levels of smoke water extract, but in case of tomato and onion, the greatest response of germination tests were obtained by level $1 \%$. Meanwhile, the carrot seeds were induced by low concentration $0.5 \%$ only.

Concerning seedlings, vegetative growth pepper, carrot and lettuce were obtained maximum values with high smoke water concentrations (2\%). On the other hand, tomato, onion and celery showed depressed results in relation to all concentrations of smoke water. Snap bean plant treated with smoke water at the concentrate of $1.5 \%$ as soil drenching combined with foliar application gave superior results of vegetative growth, yield and pod characters as well as pod chemical contents, but the decreased in all above characteristics were achieved with high level $2 \%$.

\section{REFERENCES}

Abdollahi, M.R. 2012. Effect of plant derived smoke on germination, seedling vigor and growth of rapeseed (Brassica napus L.) under laboratory and greenhouse conditions. Seed Sci. Technol. (40), 437-442.

Adetimirin, V.O. 2008. Stand establishment and early field vigor variation in a tropicalized shrunken-2maize population. Field Crops Res., 108(2), 143-149.

Adkins, S.W., Peters, N.C.B. 2001. Smoke derived from burnt vegetation stimulates germination of arable weeds. Seed Science Research, 11, 213-222.

Abu Khouder, N.A., Abubaker, A.M.S., AlMashat, K.M.E. 2019. Influence of some nitrogen fertilization and dry yeast extract levels on growth and pod yield of snap bean (Phaseolus vulgaris L.). Middle East J.Agric. Res., 8(4), 973-982.

A.O.A.C. $1990.15^{\text {th }}$ Official methods of Analysis. Association Official Analysis Chemists, Washington, D. C., USA. pp. 807-928.

Aremu, A.O., Bairu, M.W., Finnie, J.F., van Staden, J. 2012. Stimulatory role of smokewater and Karrikinolide on the photosynthetic pigment and phenolic contents of micropropagated 'Williams' bananas. Plant Growth Regulation, 67, 271-279.

Baldwin, I.T., Staszak-Kozinski, L., Davidson, R. 1994. Up in smoke. I. Smoke-derived germination cues for post-fire annual, Nicotiana attenuate Torr ex Watson. Journal of Chemical Ecology, 20, 2345-2371.

Brown, J.D., Lilleland, O. 1946. Rapid determination of potassium and sodium in plant material and soil extract by flame photometry. Proc. Amer. Hort. Sci., 48, 341346.

Brown, N.A.C., van Staden, J. 1997. Plant-derived smoke: An effective seed pre-soaking treatment for wild flower species and with potential for horticultural and vegetable crops. Seed Sci. Technol., 26, 669-673.

Chapman, H.D., Pratt, F.P. 1961. Methods of analysis for soils plant and water. Univ. of California Div. of Agric. Sci., 120-127.

Chumpookam, J., Huey-Ling, L., Ching-Chang, S., 2012. Effect of smoke-water on seed germination and seedling growth of papaya (Carica papaya cv. Tainung No.2). Hortscience, 47(6), 741-744.

Commander, L.E., Merritt, D.J., Rokich, D.P., Flematti, G.R., Dixon, K.W. 2008. Seed 
germination of Solanum spp. (Solanaceae) for use in rehabilitation and commercial industries. Aust. J. Bot., 56, 333-341.

Daws, M.I., Davies, J., Pritchard, H.W., Brown, N. A.C., van Staden, J. 2007a. Butenolide from plant-derived smoke enhances germination and seedling growth of arable weed species. plant growth regulation, 51(1), 73-82.

Daws, M.I., Pritchard, H.W., van Staden, J. 2007b. Butenolide from plant derived smoke functions as a strigolactone analogue: Evidence from parasitic weed seed germination. South Afri. J. Bot. 74, 116-120.

De-Lange, J.H., Boucher, C. 1990. Autecological studies on Audouinia capitata (Bruniaceae). Plant-derived smoke as a seed germination cue. South African J. Bot., 56, 700-703.

Demir, I., Ozden, E., Yildirim, K.C., Sahin, O. 2018. Priming with smoke-derived Karrikinolide enhances germination and transplant quality of immature and mature pepper seed lots. South African Journal of Botany. 115, 264 -268.

Dixon, K.W., Merritt, D.J., Flematti, G.R., Ghisalberti, E.L. 2009. Karrikinolide a phytoreactive compound derived from smoke with applications in horticulture, ecological restoration and agriculture. Acta Hort., 813, 155-170.

Drewes, F.E., Smith, M.T., van Staden, J. 1995. The effect of plant derived smoke water on the germination of light sensitive lettuce seed. Plant Growth Regulation, 16, 205-209.

Dubios, M., Gilles, K., Hamlton, J., Rebers, P., Smith, F. 1956. Colorimetric method for determination of sugars and related substances. Analyt. Chem., 28(3), 350-356.

Egerton-Warburton, L.M. 1998. A smoke induced alternation of the sub testa cuticle in seeds of the post fire recruiter Emmenanthe penduliflora Benth (Hydrophyllaceae). Journal of Experimental Botany (49), 1317-1327.

El-Zeiny, O.A.H. 2002. Using tissue culture as a tool for increasing the productivity of seedlings and total yield of some pepper hybris. Arab Univ. J. Agric. Sci., 10(1), 273-285.

Flematti, G.R., Ghisalberti, E.L., Dixon, K.W., Trengove, R.D. 2004. A compound from smoke that promotes seed germination. Science, 305, 977.

Flematti, G.R., Ghisalberti, E.L., Dixon, K.W., Trengove, R.D. 2009. Identification of Alkyl Substituted 2H-furo [2,3-c] pyran-2-one as germination stimulants Present in Smoke. J. Agric. Food Chem., (57): 9475-9480.

Govindaraj, M., Masilamani, P., Albert, A.V., Bhaskaran, M. 2016. Plant derived smoke stimulation for seed germination and enhancement of crop. Agricultural Reviews, 37(2):87-100.

Gupta, S., Hrdlicka, J., yemoto N.N., Nemahunguni, N.K., Gucky, T., Novak, O., Kulkarni, M.G., Dolezal, K., van Staden, J. 2020. Preparation and standardization of smoke water for seed germination and plant growth stimulation. J. Plant Growth Regulat, 39:338- 345.

Jackson, M.L. 1965. Free oxides, hydroxides, and amorphous aluminosilicates. Agronomy Monograph, (9):578-601.

Jager, A.K., Light, M.E., van Staden, J. 1996. Effects of source of plant material and temperature on the production of smoke waters that promote germination of light sensitive lettuce seeds. Environmental and Experimental Botany (36): 421-429.

Jain N., van Staden, J. 2006. A smoke-derived butenolide improves early growth of tomato seedlings. Plant growth Regul., (50):139-148.

Jain, N., Stirk, W.A., Van Staden, J. 2008. Cytokinin-and auxin-like activity of a butenolide isolated from plant-derived smoke. South Afr. J. Bot., 74, 327-331.

Jamil, M., Kanwal, M., Aslam, M.M., Shakir, S.K., Tu Malook, I.J., Rehman, S. 2014. Effect of plant-derived smoke priming on physiological and biochemical characteristics of rice under salt stress condition. Pak. J. Bot., 8:159-170.

Jardin, d.P. 2015. Plant bio-stimulants definition concept main categories and regulation. Sci. Hort., 196:3-14.

Kamran, M., Khan, A.L., Ali, L., Hussain, J., Waqas, M., Al-Harrasi, A., Kim, Q.M.Y.H., Kang, S.M., Yun, B.W., Lee, I.J. 2017. Hydroquinone a novel bioactive compound from plant derived smoke can cue seed germination of lettuce frontiers in chemistry. Front. Chem., 12, 5-30.

Keeley J.E., Fotheringham, C.J. 1998. Trace gas emissions and smoke induced seed germination. Science, 276, 1248-1250.

Kulkarni, M.G., Ascough, G.D., van Staden, J. 2007. Effects of foliar applications of smokewater and a smoke-isolated butenolide on seedling growth of okra and tomato. Hort. Sci., 42, 179-182.

Kulkarni, M.G., Ascough G.D., van Staden, J. 2008. Smoke-water and a smoke-isolated butenolide improve growth and yield of tomatoes under greenhouse conditions. Hort. Technol., 18(3), 449-454.

Kulkarni, M.G., Ascough, G.D., Verschaeve, L., Baeten, K., Arruda, M.P., van Staden, J. 2010. Effect of smoke-water and a smoke-isolated butenolide on the growth and genotoxicity of commercial onion. Scientia Horticulturae, 124, 434-439. 
Kulkarni, M.G., Light, M.E., van Staden, J. 2011. Plant-derived smoke old technology with possibilities for economic applications in agriculture and horticulture. S. Afr. J. Bot., 77, 972-979.

Light, M.E., Daws, M.I., van Staden, J. 2009. Smoke-derived butenolide: towards understanding its biological effects. S. Afr. J. Bot., 75, 1-7.

Light, M.E., Burger, B.V., Staerk, D., Kohout, L., van Staden, J. 2010. Butenolide from plant derived smoke: natural plant growth regulators with antagonistic actions on seed germination. J. Nat. Prod., 73, 267-269.

Mohamed, M.F., Abdallah, M.M.S., Khalifa, R.K.M., Ahmed, A.G., Hozayn, M. 2015. Effect of arginine and $\mathrm{GA}_{3}$ on growth, yield, mineral nutrient content and chemical constituents of faba bean plants grown in sandy soil conditions. Int. J. Chem. Tech. Res., 8(12), 187195.

Merritt, D.J., Kristiansen, M., Flematti, G.R., Turner, S.R., Ghisalberti, E.L., Trengove, R.D., Dixon, K.W. 2006. Effects of a butenolide present in smoke on light-mediated germination of Australian Asteraceae. Seed Sci.Res. 16(1), 29-35.

Aslam, M.M., Jamil, M., Khatoon, A., El- Endawy, S.E., Al-Suhaibani, N.A., Malook, I., UrRehman, S. 2017. Physiological and biochemical responces of maize (Zea mays L.) to plant derived smoke solution. Pak. J. Bot., 49(2), 435-443.

Muhammad, Q.I., Asaf, S., Jamil, M., Khatoon, A. 2014. Plant derived smoke - the magical seed sprouter: A view from traditional to recent advancements. IJCBS., 1(3), 11-27.

Odoemena, C.S. 1988. Breaking of seed coat dormancy in a medicinal plant Tetrapleura tetraptera. Journal of Agricultural Science, 111(2), 393-394.

Olsen, S.R., Sommers, L.E. 1982. Phosphorus In:Page, A. L.; R. H. Miller and D. R. Keeney (Eds). Methods of soil analysis. Part 2 Amer. Soc. Agron. Madison, W. I. USA, pp 403-430.

Papenfus, H.B., Kulkarni, M.G., Stirk, W.A., Rengasamy, K.R.R., Salomon, M.V., Piccoli, P., Bottini, R., van Staden, J. 2015. Interactions between a plant growth-promoting rhizobacterium and smoke-derived compounds and their effect on okra growth. J. Plant Nutr. Soil Sci., 178(5), 741-747.

Piper, O.S. 1947. Soil and plant Analysis. Adelaide Uni., Adelaide, Australia,258-275.

Priestly, D.A. 1986. Seed ageing: Implications for seed storage and persistence in the soil. Cornell University Press. New York, Book reviews, $304 \mathrm{pp}$.
Rao, R.G.S., Singh, P.M., Rai, M. 2006. Storability of onion seeds and effects of packaging and storage conditions on viability and vigor. Scientia Horticulturae, 110(1), 1-6.

Rathod, R.R., Gore, R.V., Bothikar, P.A. 2015. Effect of growth regulators on growth and yield of French bean (Phaseolus vulgaris L.) var. Arka Komal. J. Agric. Vet. Sci., 8(5), 36-39.

Scott, S.J., Jones, R.A., William, W.A. 1984. Review of data analysis method of seed germination. Crop. Sci., (24), 1192-1199.

Serter, S.C., Koksal, K., Anoglu, C.T., Pausas, J.G. 2018. Effect of fire-derived chemicals on germination and seedling growth in Mediterranean plant species. Basic and Applied Ecology, 30, 65-75.

Seymour, J. 2007. The New Self-Sufficient Gardener: The complete illustrated guide to planning, growing, storing and preserving your own garden produce. Dorling Kindersley Ltd.248pp.

Singh, S., Kulkarni, M.G., van Staden, J. 2014. Biochemical changes associated with gibberellic acid-like activity of smoke-water, Karrikinolide and vermicompost leachate during seedling development of Phaseolus vulgaris L. Seed Sci.Res., 24(1), 63-70.

Snedecor, C.W., Cochran, W.G. 1982. Statistical Methods. 7thEd. The Iowa State UniversityPress.Ames. lowa, USA.pp 325-330.

Sunmonu, T.O., Kulkarni, M.G., van Staden, J. 2016. Smoke-water, Karrikinolide and gibberellic acid stimulate growth in bean and maize seedlings by efficient starch mobilization and suppression of oxidative stress. S. Afr. J. Bot., 102, 4-11.

Taylor, J.L.S., van Staden, J. 1998. Plant-derived smoke solutions stimulate the growth of Lycopersicon esculentum roots in vitro. Plant Growth Regulation, 26, 77-83.

Thomas, T.H., van Staden, J. 1995. Dormancy break of celery (Apium graveolens L.) seeds by plant-derived smoke water. Plant Growth Regulation, 17, 195-198.

van Staden, J., Jager, A.K., Light, M.E., Burger, B.V. 2004. Isolation of the major germination cue from plant-derived smoke. S. Afr. J. Bot., 70, 654-659.

van Staden, J., Brown, N.A.C., Jager, A.K., Johnson, T. A. 2000. Smoke as a germination cue. Plant Species Biology, (15), 167-178.

van Staden, J., Sparg, S.G., Kulkarni, M.G., Light, M.E. 2006. Post-germination effects of the smoke-derived compound 3-methyl-2Hfuro[2,3-c] pyran-2-one, and its potential as a preconditioning agent. Field Crops Research, 98, 98-105.

Waheed, M.A., Jamil, M., Khan, M.D., Shakir, S.K., Rehman, S. 2016. Effect of plant derived 
smoke solutions on physiological and biochemical attributes of maize (Zea mays L.) under salt stress. Pak. J. Bot., 48(5), 1763-1774.

Wang, M., Wang, M., Schoettner, M., Xu. S., Paetz, S., Wilde, J., Baldwin, I.T., Groten, K. 2017.
Catechol, a major component of smoke, influences primary root growth and root hair elongation through reactive oxygen speciesmediated redox signaling. New Phytologist, 213, 1755-1770.

Table 1: The chemical analyses of smoke extract.

\begin{tabular}{|c|c|c|c|c|c|c|c|c|c|c|}
\hline \multicolumn{10}{|c|}{ Smoke extract chemical analyses } \\
\hline \multirow{3}{*}{$\mathrm{pH}$} & $\begin{array}{c}\text { E.C. } \\
(\mathrm{dSm}-1)\end{array}$ & $\begin{array}{c}\text { O.C } \\
(\%)\end{array}$ & \multirow{2}{*}{$\begin{array}{c}\text { O.M } \\
(\%)\end{array}$} & \multicolumn{3}{|c|}{$\begin{array}{c}\text { Macro elements } \\
(\%)\end{array}$} & \multicolumn{5}{c|}{$\begin{array}{c}\text { Micro elements } \\
(\%)\end{array}$} \\
\cline { 5 - 11 } & & & $\mathrm{N}$ & $\mathrm{P}$ & $\mathrm{K}$ & $\mathrm{Fe}$ & $\mathrm{Cu}$ & $\mathrm{Zn}$ & $\mathrm{Mn}$ \\
\hline 6.42 & 0.50 & 0.23 & 0.40 & 0.92 & 0.29 & 0.12 & 0.01 & 0.8 & 0.06 & 0.001 \\
\hline
\end{tabular}

Table 2: Soil physical and chemical analyses.

\begin{tabular}{|c|c|c|c|c|c|c|c|c|c|c|c|c|c|c|c|c|c|c|c|c|c|}
\hline \multicolumn{4}{|c|}{ Soil physical analyses } & \multicolumn{18}{|c|}{ Soil chemical analyses } \\
\hline \multirow[t]{2}{*}{ Text. } & \multirow[t]{2}{*}{$\begin{array}{l}n \\
2 \\
0 \\
0 \\
0\end{array}$} & \multirow[t]{2}{*}{ 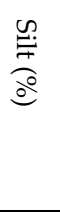 } & \multirow[t]{2}{*}{ 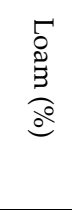 } & \multirow[t]{2}{*}{ 莒 } & \multirow{2}{*}{ 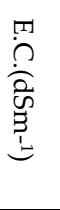 } & \multirow[t]{2}{*}{$\begin{array}{l}\stackrel{2}{2} \\
\stackrel{\infty}{0}\end{array}$} & \multicolumn{4}{|c|}{$\begin{array}{l}\text { Soluble cations } \\
(\mathrm{M} / \mathrm{L})\end{array}$} & \multicolumn{4}{|c|}{$\begin{array}{l}\text { Soluble anions } \\
(\mathrm{M} / \mathrm{L})\end{array}$} & \multicolumn{3}{|c|}{$\begin{array}{l}\text { Macro } \\
\text { elements } \\
(\mathrm{ppm})\end{array}$} & \multicolumn{4}{|c|}{$\begin{array}{l}\text { Micro elements } \\
(\mathrm{ppm})\end{array}$} \\
\hline & & & & & & & $\mathrm{Ca}^{+2}$ & $\begin{array}{l}\mathrm{Mg} \\
+2\end{array}$ & $\mathrm{Na}^{+}$ & $\begin{array}{l}\mathrm{K} \\
+\end{array}$ & $\begin{array}{l}\mathrm{CO}_{3} \\
-2\end{array}$ & $\begin{array}{l}\mathrm{HCO} \\
-3\end{array}$ & $\begin{array}{l}\mathrm{Cl}^{-} \\
2\end{array}$ & $\mathrm{SO}_{4}{ }^{-2}$ & $\mathrm{~N}$ & $\mathrm{P}$ & K & $\mathrm{Fe}$ & $\begin{array}{l}\mathrm{C} \\
\mathrm{u}\end{array}$ & $\mathrm{Zn}$ & $\mathrm{Mn}$ \\
\hline $\begin{array}{l}\text { Sandy } \\
\text { loam }\end{array}$ & 80.3 & 2.0 & 17.6 & 8.4 & 0.2 & 5.2 & 1.0 & 0.5 & 0.3 & $\begin{array}{l}0 \\
. \\
2\end{array}$ & 0.0 & 0.2 & 0.5 & 1.3 & $\begin{array}{l}4 \\
0\end{array}$ & $\begin{array}{l}6 \\
6\end{array}$ & $\begin{array}{l}4 \\
0\end{array}$ & 3.0 & 0.8 & 1.0 & 1.5 \\
\hline
\end{tabular}

Table 3: Least significant difference between smoke water concentrations for germination percentage of some vegetable seeds in the two seasons of 2019 and 2020.

\begin{tabular}{ccccccccccc}
\hline & \multicolumn{1}{c}{ Germination percentage (\%). } \\
\cline { 2 - 11 } & \multicolumn{1}{c}{ 1st season } & \multicolumn{1}{c}{ Smoke water concentrations } \\
\cline { 2 - 11 } & $0 \%$ & $0.5 \%$ & $1 \%$ & $1.5 \%$ & $2 \%$ & $0 \%$ & $0.5 \%$ & $1 \%$ & $1.5 \%$ & $2 \%$ \\
L.S.D at $5 \%$ & 0.02 & 0.02 & 0.05 & 0.81 & 0.28 & 0.21 & 0.17 & 0.18 & 0.51 & 0.29 \\
\hline
\end{tabular}

Table 4: Least significant difference between smoke water extract concentrations for germination rate of some vegetable seeds in the two seasons of 2019 and 2020.

\begin{tabular}{ccccccccccc}
\hline & \multicolumn{1}{c}{ Germination rate. } \\
\cline { 2 - 12 } & \multicolumn{1}{c}{ 1st season } & \multicolumn{7}{c}{ Smoke water concentrations } \\
\cline { 2 - 12 } & $0 \%$ & $0.5 \%$ & $1 \%$ & $1.5 \%$ & $2 \%$ & $0 \%$ & $0.5 \%$ & $1 \%$ & $1.5 \%$ & $2 \%$ \\
L.S.D at $5 \%$ & 0.03 & 0.05 & 0.04 & 0.03 & 0.05 & 0.12 & 0.07 & 0.29 & 0.22 & 0.11 \\
\hline
\end{tabular}


Table 5: Effect of smoke water extract concentrations on some vegetable's seedlings growth at the two seasons of 2019 and 2020.

\begin{tabular}{|c|c|c|c|c|c|c|c|c|c|c|c|c|c|c|c|c|c|c|c|c|c|c|c|c|c|}
\hline \multirow[b]{3}{*}{ Vegetables } & \multicolumn{5}{|c|}{ Seedling fresh weight $(\mathrm{g})$} & \multicolumn{5}{|c|}{ Seedling dry weight $(\mathrm{g})$} & \multicolumn{5}{|c|}{ Seedling height $(\mathrm{cm})$} & \multicolumn{5}{|c|}{ Seedling number of leaves } & \multicolumn{5}{|c|}{ Chlorophyll (SPAD) } \\
\hline & \multicolumn{25}{|c|}{ Smoke water concentrations ${ }^{1 \text { st }}$ season } \\
\hline & $0 \%$ & $0.5 \%$ & $1 \%$ & $1.5 \%$ & $2 \%$ & $0 \%$ & $0.5 \%$ & $1 \%$ & $1.5 \%$ & $2 \%$ & $0 \%$ & $0.5 \%$ & $1 \%$ & $\begin{array}{l}1.5 \\
\%\end{array}$ & $2 \%$ & $0 \%$ & $0.5 \%$ & $1 \%$ & $1.5 \%$ & $2 \%$ & $0 \%$ & $0.5 \%$ & $1 \%$ & $1.5 \%$ & $2 \%$ \\
\hline Tomato & 3.08 & 2.86 & 2.46 & 2.41 & 2.19 & 0.34 & 0.29 & 0.25 & 0.19 & $\begin{array}{c}0.1 \\
7 \\
\end{array}$ & $\begin{array}{c}25.5 \\
3 \\
\end{array}$ & $\begin{array}{c}23.5 \\
0 \\
\end{array}$ & $\begin{array}{c}17.4 \\
0 \\
\end{array}$ & $\begin{array}{c}15.3 \\
1 \\
\end{array}$ & 13.77 & 4.70 & 4.33 & 4.14 & 3.70 & 3.00 & 50.30 & 48.33 & 46.00 & 44.96 & 43.00 \\
\hline Pepper & 1.18 & 1.55 & 1.73 & 1.80 & 1.97 & 0.15 & 0.17 & 0.22 & 0.29 & $\begin{array}{c}0.3 \\
9 \\
\end{array}$ & 9.53 & $\begin{array}{c}10.1 \\
4 \\
\end{array}$ & $\begin{array}{c}11.8 \\
3 \\
\end{array}$ & $\begin{array}{c}12.0 \\
7 \\
\end{array}$ & 12.56 & 5.50 & 5.70 & 5.68 & 6.07 & 7.43 & 27.46 & 28.20 & 28.33 & 31.63 & 39.03 \\
\hline Onion & 1.45 & 1.27 & 1.16 & 1.12 & 0.94 & 0.21 & 0.19 & 0.15 & 0.12 & $\begin{array}{c}0.1 \\
0 \\
\end{array}$ & $\begin{array}{c}27.4 \\
6 \\
\end{array}$ & $\begin{array}{c}23.4 \\
2 \\
\end{array}$ & $\begin{array}{c}20.5 \\
4 \\
\end{array}$ & $\begin{array}{c}18.7 \\
8 \\
\end{array}$ & 18.17 & 3.26 & 3.10 & 3.06 & 3.01 & 2.70 & 45.30 & 33.40 & 33.66 & 31.17 & 21.00 \\
\hline Carrot & 0.58 & 0.92 & 1.14 & 1.16 & 2.06 & 0.07 & 0.08 & 0.42 & 0.45 & $\begin{array}{c}0.6 \\
1 \\
\end{array}$ & $\begin{array}{c}14.6 \\
3 \\
\end{array}$ & $\begin{array}{c}15.8 \\
0 \\
\end{array}$ & $\begin{array}{c}15.8 \\
8 \\
\end{array}$ & $\begin{array}{c}17.0 \\
4 \\
\end{array}$ & 17.17 & 2.50 & 3.11 & 3.20 & 3.46 & 3.71 & 13.12 & 14.60 & 18.00 & 19.17 & 24.27 \\
\hline Lettuce & 2.04 & 2.64 & 2.67 & 2.70 & 3.03 & 0.11 & 0.19 & 0.22 & 0.23 & $\begin{array}{c}0.2 \\
9 \\
\end{array}$ & $\begin{array}{c}18.5 \\
3\end{array}$ & $\begin{array}{c}20.0 \\
3\end{array}$ & $\begin{array}{c}22.9 \\
6\end{array}$ & $\begin{array}{c}24.0 \\
7\end{array}$ & 24.17 & 2.90 & 3.40 & 3.73 & 4.03 & 4.26 & 15.86 & 18.07 & 20.80 & 24.70 & 30.46 \\
\hline Celery & 0.76 & 0.54 & 0.46 & 0.45 & 0.42 & 0.11 & 0.09 & 0.06 & 0.05 & $\begin{array}{c}0.0 \\
2\end{array}$ & 8.66 & 7.70 & 7.16 & 7.04 & 6.40 & 3.62 & 3.32 & 3.16 & 3.05 & 3.00 & 29.83 & 27.43 & 19.31 & 13.50 & 11.23 \\
\hline L.S.D at $5 \%$ & 0.01 & 0.05 & 0.03 & 0.01 & 0.03 & 0.01 & 0.01 & 0.01 & 0.01 & $\begin{array}{c}0.0 \\
1\end{array}$ & 0.16 & 0.07 & 0.20 & 0.06 & 0.15 & 0.09 & 0.06 & 0.03 & 0.09 & 0.10 & 1.04 & 1.28 & 1.93 & 0.60 & 1.12 \\
\hline \multirow[b]{2}{*}{ Vegetables } & \multicolumn{25}{|c|}{ Smoke water concentrations ${ }^{2 \text { nd }}$ season } \\
\hline & $0 \%$ & $0.5 \%$ & $1 \%$ & $1.5 \%$ & $2 \%$ & $0 \%$ & $0.5 \%$ & $1 \%$ & $1.5 \%$ & $2 \%$ & $0 \%$ & $0.5 \%$ & $1 \%$ & $\begin{array}{c}1.5 \\
\% \\
\end{array}$ & $2 \%$ & $0 \%$ & $0.5 \%$ & $1 \%$ & $1.5 \%$ & $2 \%$ & $0 \%$ & $0.5 \%$ & $1 \%$ & $1.5 \%$ & $2 \%$ \\
\hline Tomato & 3.02 & 2.50 & 2.46 & 2.42 & 2.12 & 0.34 & 0.27 & 0.23 & 0.18 & $\begin{array}{c}0.1 \\
6 \\
\end{array}$ & $\begin{array}{c}25.9 \\
3 \\
\end{array}$ & $\begin{array}{c}24.1 \\
6 \\
\end{array}$ & $\begin{array}{c}17.0 \\
0 \\
\end{array}$ & $\begin{array}{c}15.0 \\
9 \\
\end{array}$ & 13.50 & 4.50 & 4.33 & 4.07 & 3.40 & 3.01 & 48.50 & 46.36 & 44.63 & 43.13 & 43.08 \\
\hline Pepper & 1.13 & 1.37 & 1.74 & 1.78 & 2.29 & 0.14 & 0.18 & 0.25 & 0.34 & $\begin{array}{c}0.4 \\
3 \\
\end{array}$ & 9.23 & $\begin{array}{c}10.0 \\
0 \\
\end{array}$ & $\begin{array}{c}11.2 \\
5 \\
\end{array}$ & $\begin{array}{c}12.3 \\
5 \\
\end{array}$ & 12.60 & 5.55 & 5.64 & 5.65 & 6.00 & 7.25 & 28.00 & 28.10 & 30.26 & 31.03 & 43.00 \\
\hline Onion & 2.04 & 1.56 & 1.29 & 1.14 & 1.03 & 0.22 & 0.15 & 0.15 & 0.12 & $\begin{array}{c}0.1 \\
0 \\
\end{array}$ & $\begin{array}{c}27.6 \\
0 \\
\end{array}$ & $\begin{array}{c}23.8 \\
0 \\
\end{array}$ & $\begin{array}{c}21.0 \\
2 \\
\end{array}$ & $\begin{array}{c}18.8 \\
3 \\
\end{array}$ & 18.32 & 3.13 & 3.10 & 3.07 & 3.05 & 2.60 & 42.60 & 40.00 & 36.66 & 22.46 & 22.00 \\
\hline Carrot & 0.62 & 0.85 & 1.17 & 2.01 & 2.04 & 0.08 & 0.42 & 0.45 & 0.48 & $\begin{array}{c}0.5 \\
5 \\
\end{array}$ & $\begin{array}{c}15.5 \\
5 \\
\end{array}$ & $\begin{array}{c}15.6 \\
1 \\
\end{array}$ & $\begin{array}{c}15.8 \\
4 \\
\end{array}$ & $\begin{array}{c}17.0 \\
5 \\
\end{array}$ & 17.10 & 2.83 & 2.97 & 3.24 & 3.40 & 3.64 & 12.73 & 14.56 & 16.66 & 19.40 & 24.60 \\
\hline Lettuce & 2.16 & 2.43 & 2.67 & 2.68 & 2.84 & 0.14 & 0.22 & 0.23 & 0.26 & $\begin{array}{c}0.2 \\
9 \\
\end{array}$ & $\begin{array}{c}18.9 \\
3\end{array}$ & $\begin{array}{c}21.5 \\
2 \\
\end{array}$ & $\begin{array}{c}21.8 \\
3 \\
\end{array}$ & $\begin{array}{c}24.0 \\
0\end{array}$ & 24.11 & 3.00 & 3.50 & 3.70 & 4.07 & 4.30 & 15.40 & 18.00 & 19.60 & 24.00 & 32.33 \\
\hline Celery & 0.73 & 0.59 & 0.48 & 0.42 & 0.45 & 0.13 & 0.06 & 0.08 & 0.05 & $\begin{array}{c}0.0 \\
2\end{array}$ & 8.31 & 8.09 & 7.11 & 6.78 & 6.54 & 3.53 & 3.38 & 3.10 & 3.02 & 3.00 & 31.10 & 27.00 & 17.10 & 13.60 & 11.50 \\
\hline L.S.D at $5 \%$ & 0.05 & 0.17 & 0.02 & 0.02 & 0.04 & 0.01 & 0.17 & 0.02 & 0.01 & $\begin{array}{c}0.0 \\
1\end{array}$ & 0.17 & 0.10 & 0.10 & 0.05 & 0.05 & 0.03 & 0.11 & 0.02 & 0.06 & 0.06 & 0.66 & 1.15 & 0.79 & 1.15 & 0.55 \\
\hline
\end{tabular}


Table 6: Effect of smoke water extract on Phaseolus vulgaris cv. Paulista vegetative growth in the two seasons of 2019 and 2020.

\begin{tabular}{|c|c|c|c|c|c|c|c|}
\hline Treatments & $\begin{array}{l}\text { Plant } \\
\text { length } \\
(\mathrm{cm})\end{array}$ & $\begin{array}{l}\text { No. of } \\
\text { branches } \\
\text { /plant }\end{array}$ & $\begin{array}{l}\text { No. of } \\
\text { leaves } \\
\text { /plant }\end{array}$ & $\begin{array}{l}\text { plant } \\
\text { Fresh } \\
\text { wt. (g) }\end{array}$ & $\begin{array}{l}\text { Dry matter } \\
\text { accumulation } \\
(\%)\end{array}$ & $\begin{array}{c}\text { Ave. } \\
\text { roots } \\
\text { length } \\
(\mathrm{cm})\end{array}$ & $\begin{array}{l}\text { No. of } \\
\text { secondary } \\
\text { roots }\end{array}$ \\
\hline & \multicolumn{7}{|c|}{ 1st season } \\
\hline $\mathrm{T} 1$ & 29.08 & 5.11 & 12.33 & 32.32 & 17.54 & 18.33 & 6.61 \\
\hline $\mathrm{T} 2$ & 31.07 & 5.25 & 12.83 & 34.88 & 18.22 & 20.62 & 6.93 \\
\hline T3 & 31.55 & 7.04 & 13.25 & 40.94 & 18.69 & 21.04 & 7.66 \\
\hline $\mathrm{T} 4$ & 33.33 & 7.34 & 15.97 & 44.90 & 18.83 & 25.68 & 8.61 \\
\hline T5 & 34.13 & 7.47 & 17.05 & 46.71 & 20.29 & 26.51 & 9.43 \\
\hline T6 & 40.70 & 9.79 & 17.19 & 52.05 & 21.61 & 28.37 & 9.16 \\
\hline T7 & 43.30 & 9.84 & 17.37 & 54.12 & 26.61 & 29.36 & 9.58 \\
\hline $\mathrm{T} 8$ & 22.72 & 4.12 & 9.72 & 31.45 & 13.04 & 17.17 & 5.58 \\
\hline T9 & 22.10 & 3.97 & 8.91 & 13.28 & 12.70 & 16.68 & 5.45 \\
\hline \multirow[t]{2}{*}{ L.S.D at $5 \%$} & 1.22 & 0.41 & 0.68 & 0.73 & 0.66 & 3.58 & 0.40 \\
\hline & \multicolumn{7}{|c|}{ 2nd season } \\
\hline $\mathrm{T} 1$ & 30.01 & 5.94 & 12.34 & 37.21 & 18.25 & 18.37 & 8.08 \\
\hline $\mathrm{T} 2$ & 34.17 & 6.55 & 12.54 & 40.15 & 18.49 & 21.16 & 8.25 \\
\hline T3 & 36.55 & 7.42 & 13.62 & 45.19 & 18.84 & 21.35 & 9.41 \\
\hline $\mathrm{T} 4$ & 36.90 & 7.88 & 15.14 & 48.01 & 18.89 & 26.33 & 10.58 \\
\hline T5 & 38.55 & 8.14 & 16.52 & 49.04 & 20.40 & 26.53 & 11.03 \\
\hline T6 & 44.89 & 9.58 & 17.10 & 56.33 & 21.30 & 27.34 & 11.95 \\
\hline $\mathrm{T} 7$ & 48.20 & 11.28 & 17.35 & 62.92 & 24.97 & 29.25 & 12.25 \\
\hline $\mathrm{T} 8$ & 27.03 & 4.27 & 9.83 & 32.39 & 15.08 & 19.41 & 7.08 \\
\hline T9 & 22.42 & 3.99 & 9.21 & 30.45 & 13.13 & 18.47 & 5.93 \\
\hline
\end{tabular}

T1: Control (0 concentration of smoke water).

T2: Foliar application with smoke water at concentration of $0.5 \%$.

T3: Foliar application plus soil drenching with smoke water at concentration of $0.5 \%$.

T4: Foliar application with smoke water at concentration of $1 \%$.

T5: Foliar application plus soil drenching with smoke water at concentration of $1 \%$.

T6: Foliar application with smoke water at concentration of $1.5 \%$.

T7: Foliar application plus soil drenching with smoke water at concentration of $1.5 \%$.

T8: Foliar application with smoke water at concentration of $2 \%$.

T9: Foliar application plus soil drenching with smoke water at concentration of $2 \%$. 
Table 7: Effect of smoke water extract on Phaseolus vulgaris cv. Paulista yield and pod characters in the two seasons of 2019 and 2020.

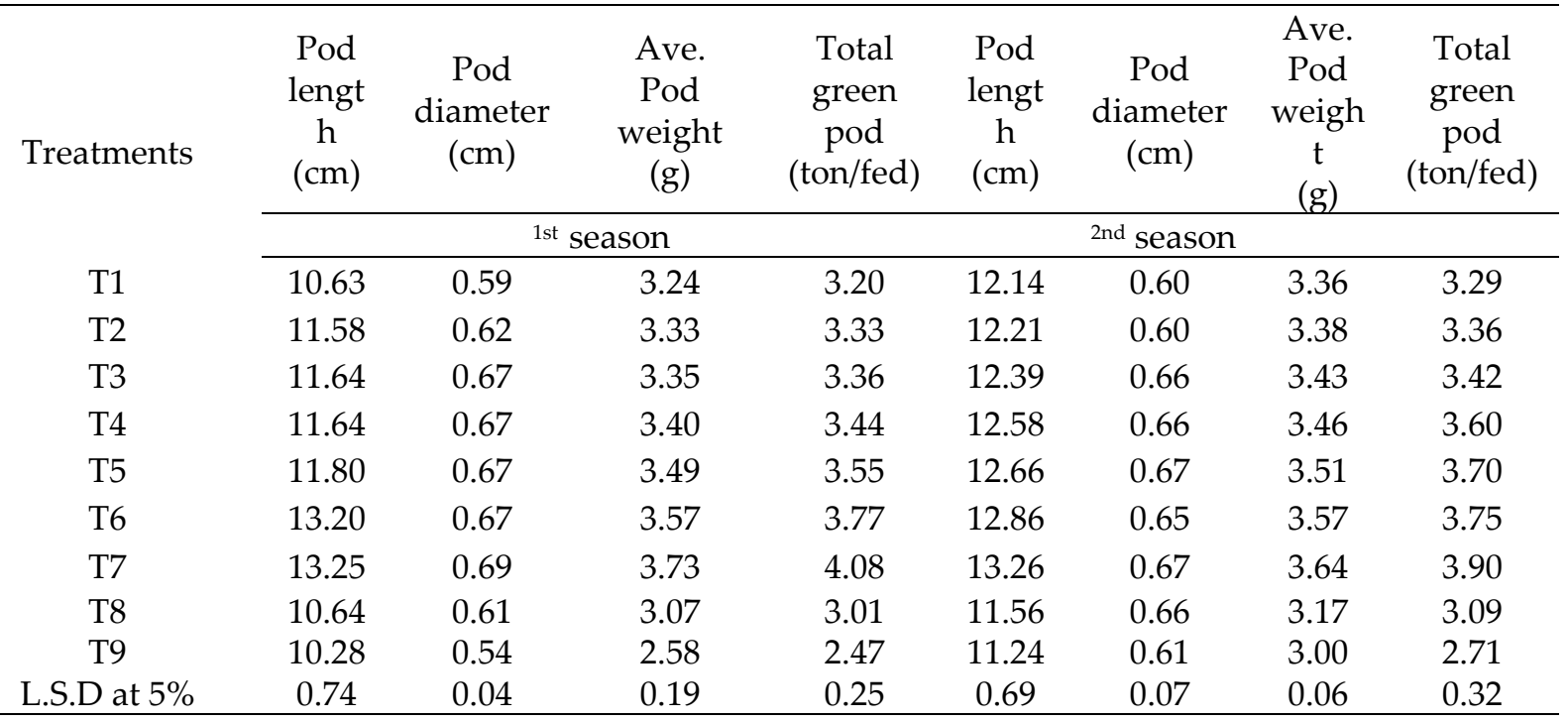

T1: Control (0 concentration of smoke water). T2: Foliar application with smoke water at concentration of $0.5 \%$

T3: Foliar application plus soil drenching with smoke water at concentration of $0.5 \%$.

T4: Foliar application with smoke water at concentration of $1 \%$.

T5: Foliar application plus soil drenching with smoke water at concentration of $1 \%$.

T6: Foliar application with smoke water at concentration of $1.5 \%$.

T7: Foliar application plus soil drenching with smoke water at concentration of $1.5 \%$.

T8: Foliar application with smoke water at concentration of $2 \%$.

T9: Foliar application plus soil drenching with smoke water at concentration of $2 \%$

Table 8: Effect of smoke water extract on Phaseolus vulgaris cv. Paulista pod chemical contents in the two seasons of 2019 and 2020.

\begin{tabular}{ccccccccc}
\hline & $\begin{array}{c}\mathrm{K} \\
\text { Treatments }\end{array}$ & $\begin{array}{c}\mathrm{P} \\
(\%)\end{array}$ & $\begin{array}{c}\text { Protei } \\
\mathrm{n} \\
(\%)\end{array}$ & $\begin{array}{c}\text { Carbohydrate } \\
(\%)\end{array}$ & $\begin{array}{c}\mathrm{K} \\
(\%)\end{array}$ & $\begin{array}{c}\mathrm{P} \\
(\%)\end{array}$ & $\begin{array}{c}\text { Protein } \\
(\%)\end{array}$ & $\begin{array}{c}\text { Carbohydrate } \\
(\%)\end{array}$ \\
\cline { 2 - 8 } T1 & \multicolumn{3}{c}{ 1st season } \\
\cline { 2 - 8 } T2 & 2.32 & 0.23 & 14.50 & 8.34 & 2.38 & 0.24 & 14.40 & 8.52 \\
T3 & 2.32 & 0.24 & 14.56 & 8.35 & 2.38 & 0.25 & 14.43 & 8.53 \\
T4 & 2.36 & 0.24 & 14.58 & 8.35 & 2.40 & 0.25 & 14.49 & 8.55 \\
T5 & 2.37 & 0.25 & 14.67 & 8.37 & 2.41 & 0.26 & 14.50 & 8.56 \\
T6 & 2.41 & 0.26 & 14.98 & 8.38 & 2.42 & 0.28 & 14.50 & 8.56 \\
T7 & 2.71 & 0.33 & 17.70 & 8.89 & 2.55 & 0.37 & 17.24 & 8.68 \\
T8 & 2.77 & 0.37 & 19.11 & 9.06 & 2.68 & 0.38 & 17.40 & 8.79 \\
T9 & 2.21 & 0.21 & 12.32 & 7.56 & 2.30 & 0.22 & 10.73 & 8.05 \\
L.S.D. at 5\% & 2.10 & 0.21 & 10.50 & 7.17 & 2.18 & 0.16 & 10.15 & 7.33 \\
\hline
\end{tabular}

T1: Control (0 concentration of smoke water)

T2: Foliar application with smoke water at concentration of $0.5 \%$

T3: Foliar application plus soil drenching with smoke water at concentration of $0.5 \%$.

T4: Foliar application with smoke water at concentration of $1 \%$.

T5: Foliar application plus soil drenching with smoke water at concentration of $1 \%$.

T6: Foliar application with smoke water at concentration of $1.5 \%$.

T7: Foliar application plus soil drenching with smoke water at concentration of $1.5 \%$.

T8: Foliar application with smoke water at concentration of $2 \%$.

T9: Foliar application plus soil drenching with smoke water at concentration of $2 \%$. 

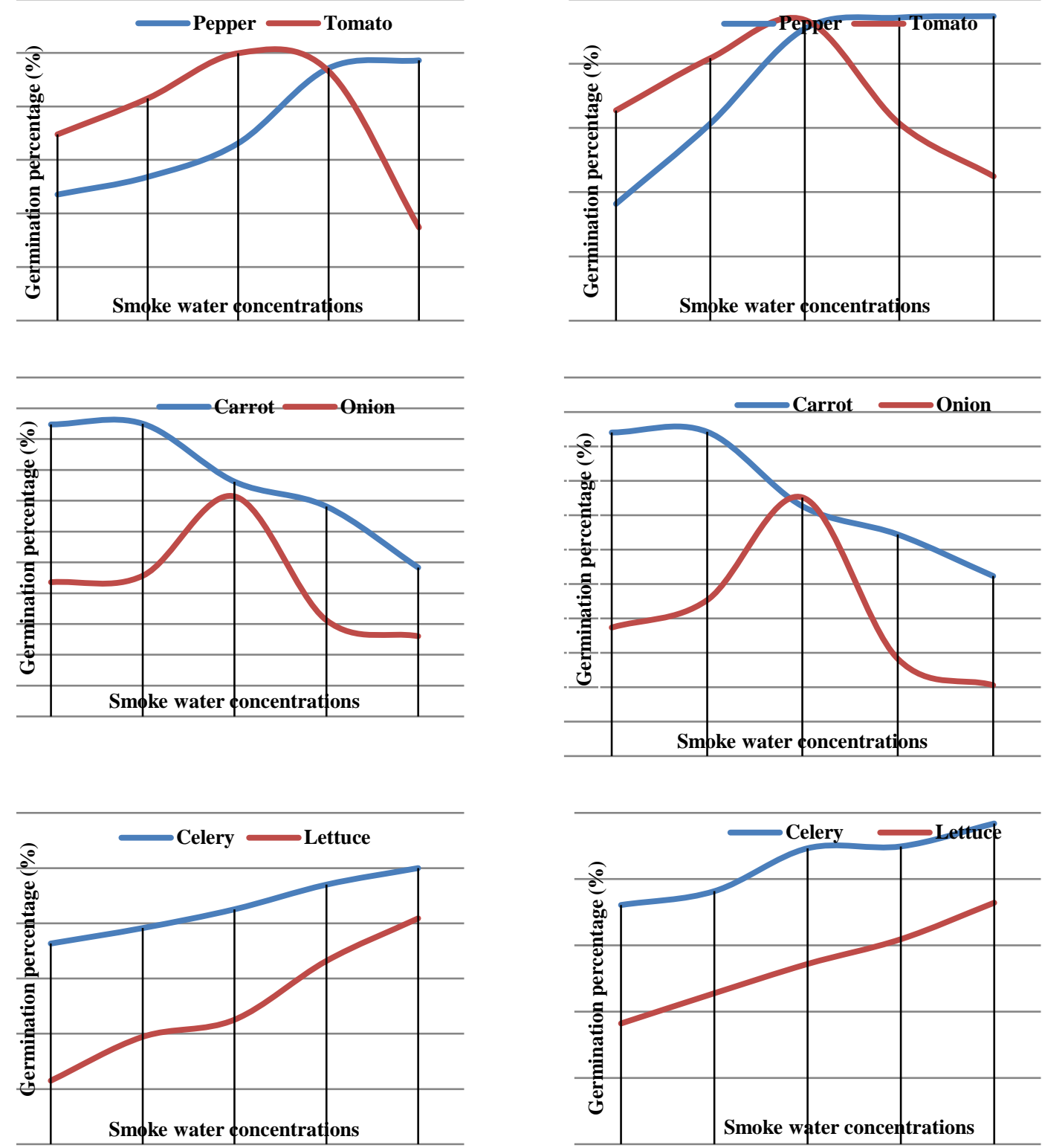

Season 2020

Season 2019

Figure 1: Effect of smoke water extract at different concentrations on seeds germination percentage of some vegetable seeds in the seasons of 2019 and 2020. 


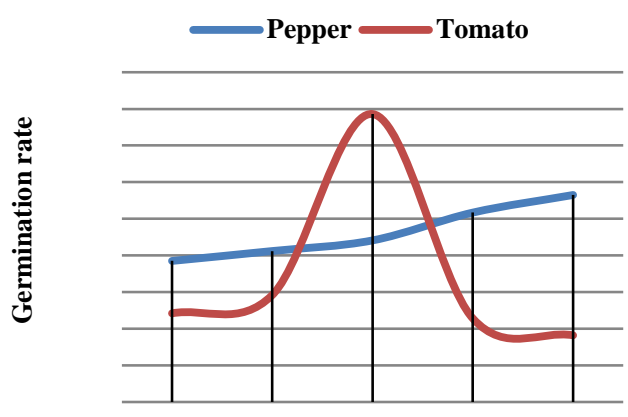

Smoke water extract concentrations

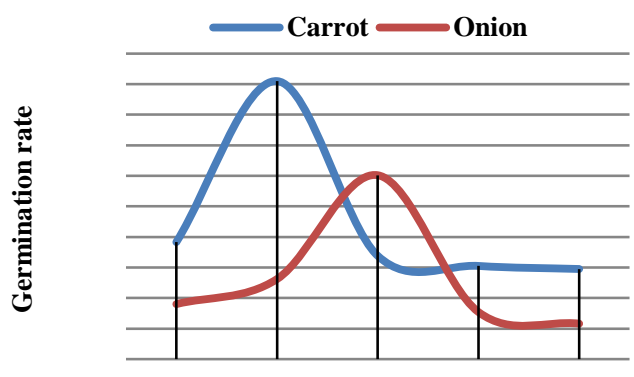

Smoke water extract concentrations

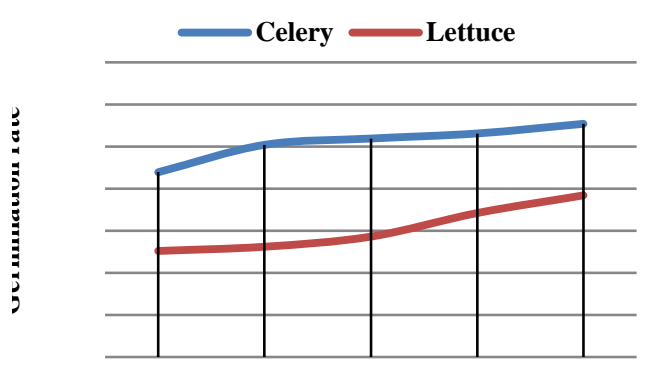

Smoke water extract concentrations
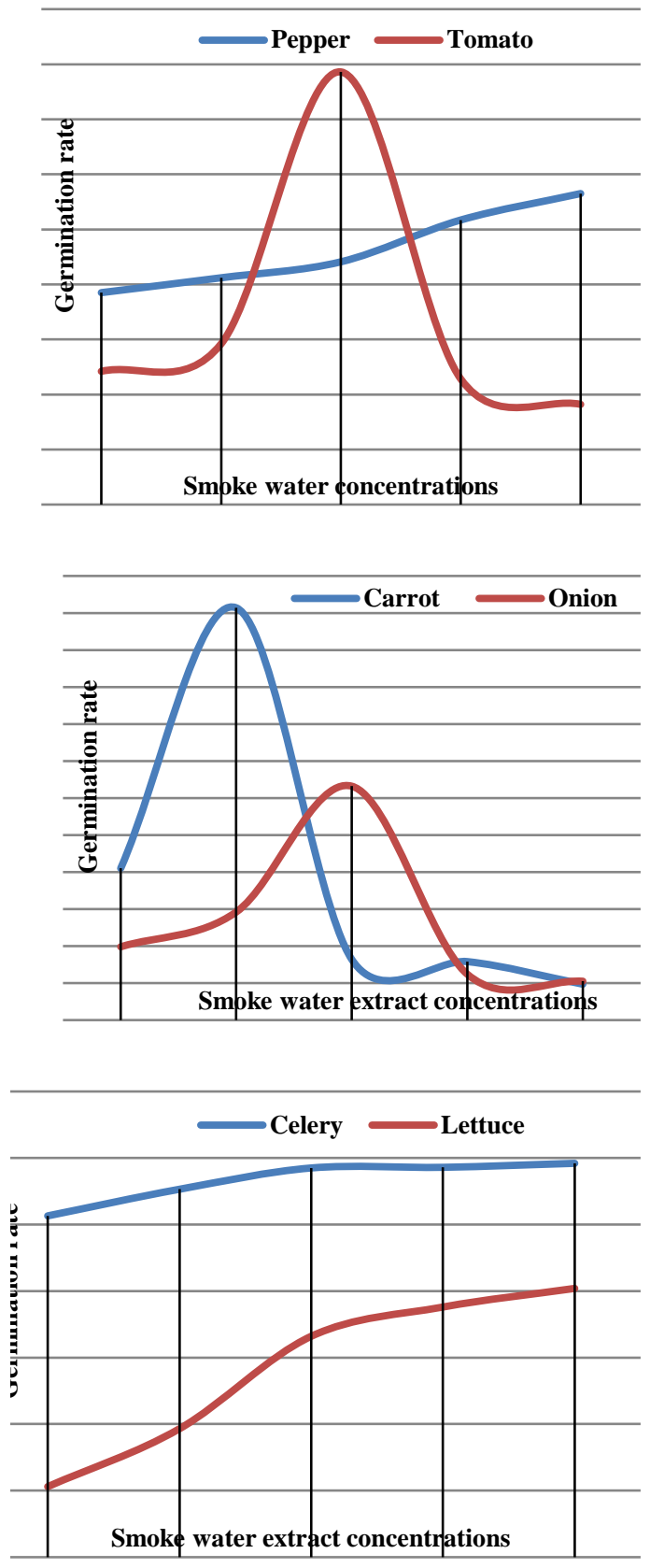

Season 2020

Season 2019

Figure 2: Effect of smoke water extract at different concentrations on seeds germination rate of some vegetable seeds in the seasons of 2019 and 2020. 


\section{تاثير ماء الدخان على إنبات بذور ونو شتلات بعض نباتات الخضر و إنتاجية المحصول الأخضر اللفاصوليا.}

$$
\begin{aligned}
& \text { هالة حسن أبو النور } \\
& \text { بجوث الخضر - معهـ بجوث البساتين- مركز البحوث الزراعية - الجيزة- مصر. } \\
& \text { wittylight@Gmail.com:البريد الإيكتروني للباحث الرئيسي }
\end{aligned}
$$

استخدمت 4 تركيزات (0.5\% - 1\% - 1.5\% و2\%) من مستخلص ماء الدخان الى جانب ماء الصنبور (كنترول) باعتبارها معاملة أرضية أثناء

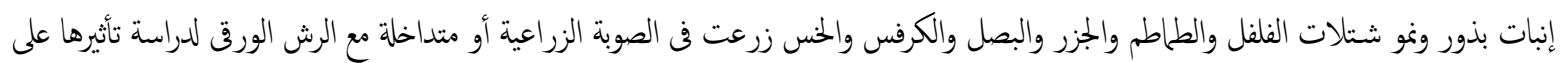

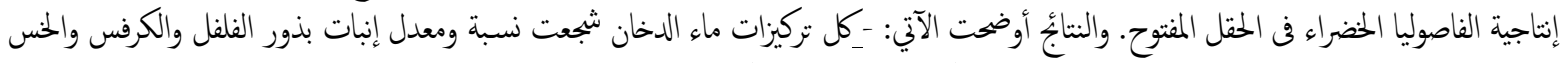

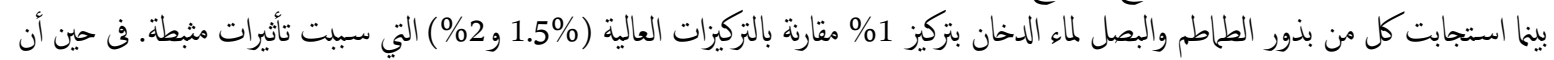

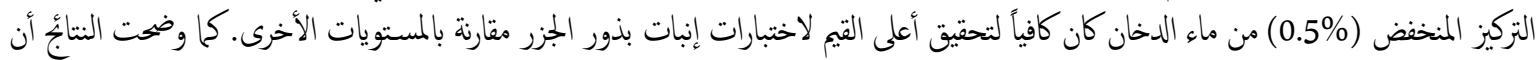

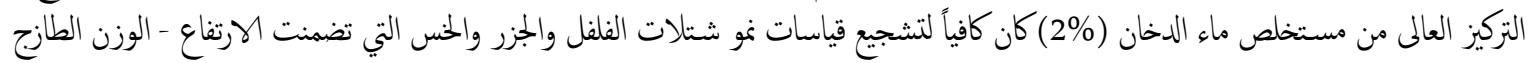

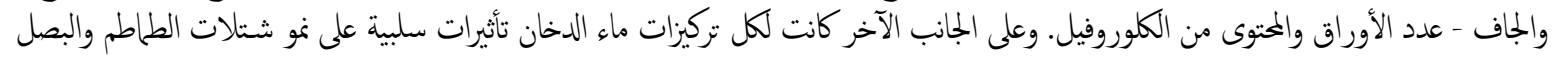

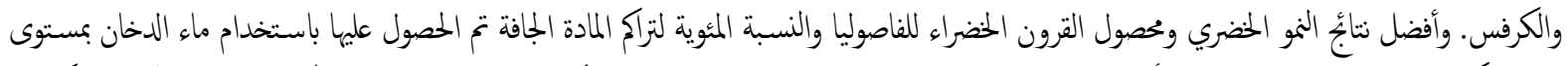

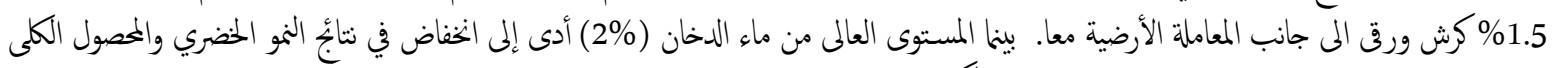

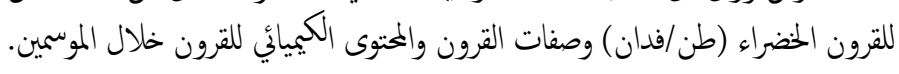
الكلمات الاسترثادية: ماء الدخان - الشتلات - الفاصوليا. 